Gerión. Revista de Historia Antigua

ISSN: 0213-0181

https://dx.doi.org/10.5209/geri.74788

\title{
Changing Protagonists: Managing Economic Activities in Late Antique Lusitania $^{1}$
}

\author{
André Carneiro ${ }^{2}$
}

Recibido: 24 de octubre de 2019 / Aceptado: 12 de mayo de 2020

\begin{abstract}
The Roman province of Lusitania went through a sequence of processes from the end of the $4^{\text {th }}$ century onwards that resulted in the end of the classical landscape. The Christian Church gradually replaced private entrepreneurship in the management of the main economic activities and the organization of the daily activities. This process is difficult to characterize, but some archaeological evidence, from specific sites and from the analysis of the rural settlement patterns, emerges. Some considerations will be presented here, trying to contextualize certain mechanisms of change.
\end{abstract}

Keywords: Settlement Patterns; Villa; Rural Economy; Agriculture.

\section{[es] Cambio de protagonistas: la gestión de las actividades económicas en la Lusitania tardoantigua}

Resumen. La provincia romana de Lusitania atravesó, desde el final del s. IV d.C., una serie de procesos continuados que tuvieron como consecuencia el final del paisaje clásico. La iglesia cristiana reemplazó de manera progresiva a la iniciativa privada en la gestión de las principales actividades económicas y en la organización de las actividades cotidianas. El proceso es difícil de caracterizar, pero se cuenta con algunas evidencias arqueológicas, en yacimientos específicos y en el análisis de los patrones de asentamiento rural. Se presentarán aquí algunas consideraciones con la intención de contextualizar algunos de los mecanismos de cambio.

Palabras clave: patrones de asentamiento; villa; economía rural; agricultura.

Summary: 1 . The scenario - or a rapidly changing world. 2 . There is nobody home: the end of the villae. 3 . The end of the middle class: changes in the rural world. 4. Discourse of the souls: power and influence. 5. References.

Cómo citar: Carneiro, A. (2021): Changing Protagonists: Managing Economic Activities in Late Antique Lusitania, en Gerión 39/1, 197-220.

1 This paper was written during 2016 - it is a crossroad of many perspectives that were cherished since then. Project Ref. UID/EAT/00112/2013, financed by National Funds through FCT/Fundação para a Ciência e a Tecnologia (many thanks go to CHAIA for the translation of the text).

2 Universidade de Évora, Researcher at CHAIA-UÉ and CECH/FLUC.

E-mail: ampc@uevora.pt

ORCID: 0000-0002-0824-3301 


\section{The scenario - or a rapidly changing world}

At some moment in the first half of the $6^{\text {th }}$ century, a boat sunk in the Mediterranean Ocean. In itself, this fact alone is nothing new: in every strategic point in all navigation routes, the bottom of the ocean is littered with shipwrecks that took place in the thousand years between 400 B.C. and late 600 A.D. ${ }^{3}$ What makes this ship-known as Marzamemi B- so relevant is its load and what it shows us about that time: the vessel was loaded with a 'ready-made church' comprising semi-manufactured elements, which included foundations, shafts and capitals, the altar table, and the pulpit for a temple under construction somewhere. All these elements had different origins: marble from the island of Proconesos, Thessaly, and eventually Mount Pentelikon, in Asia Minor. ${ }^{4}$ The ship carried an overall estimate mass of 164 tons and occupied $61 \mathrm{~m}^{3}$. Just out of curiosity, a column was found therein, which due to its $640 \times 185 \mathrm{~cm}$ and 49 tons is the heaviest piece ever found in a Mediterranean shipwreck. ${ }^{5}$ In addition to the church in the Marzamemi shipwreck, there are more Christian temple constructions, loaded in Asia Minor for assembly in other places. There are a few of these previously manufactured churches in the province of Ravenna and Cyrenaica, and this shipwreck, which took place in the south-east of the island of Sicily, is proof of an active route joining these areas.

The shipwreck dates back to 540. A time when the East decides to react: in the political scenario, Justinian was actively looking to rebuild his Empire by leading large-scale military campaigns in North Africa. However, the leading character is a different one here: Marzamemi documents the attempt to standardise the architectural programme of churches and their decorations. At a time of great instability, the Church assumes a strong position: an Emperor, a doctrine and a faith, building common temples throughout the Christian space.

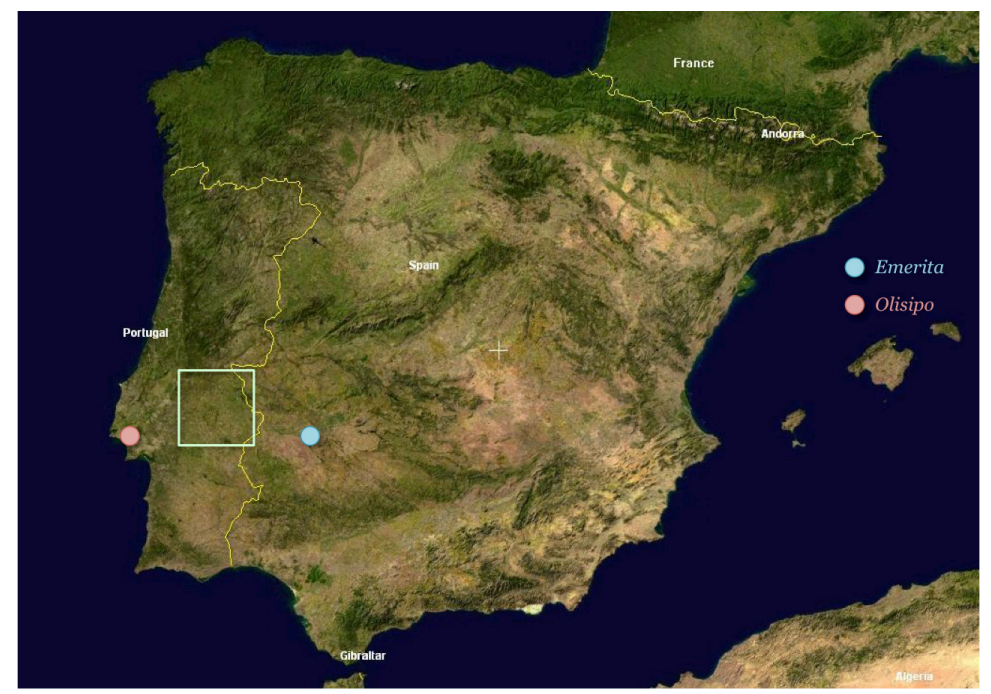

Fig. 1. South of Lusitania in the Iberian Peninsula

From this stage on, maritime traffic falls abruptly: Parker 1992, chart 1. For an overview in the commercial trends, see McCormick 2012.

Sodini 2002, 133. For a complete description of the ship, please refer to Kapitän 1980.

Balletti et alii 2015, 8 . 
The mid-6th century is a time for recovery, an attempt at pulling through after many years of turmoil and devastation. For the East, the momentum is for victory; however, for the West, history changed entirely. In 409, we entered the loss of Hispania, as designated by the chronicler Orosio, for the simultaneous settlement of the Suebi, Vandals, and Alans, which took place while Constantine III was usurping the prefecture of Gaul. ${ }^{6}$ However, even more than political facts, one should consider the changes in the perception of spaces of life and death. On one hand, these changes were motivated by new positions held by local aristocracies in their relationship with the surrounding communities. On the other hand, although the leading characters were often the same, we have a key player in linking territories and organising the populations therein entering the scene: the Church, which is in the process of establishing itself, with an increasingly prominent role in the rural world's everyday life. This study intends to analyse some of the changes that are present in the rural landscape, south in the province of Lusitania (Fig. 1).

\section{There is nobody home: the end of the villae}

Small and urgent archaeological works took place in 2015, in Fronteira, in the Roman place of Monte de São Francisco. ${ }^{7}$ Here, a villa was previously identified with abundant surface materials, including a remarkable African red slip ware collection, which allowed for an estimate of the site's floruit to around the $4^{\text {th }}$ century (Fig. 2):

\begin{tabular}{|c|c|c|c|c|c|}
\hline Formas & Séc. II & Séc. III & Séc. IV & $\overline{S e ́ c . V}$ & $\overline{\text { Séc. VI }}$ \\
\hline \multicolumn{6}{|l|}{ H. 27} \\
\hline H.45A & & 1 & & & \\
\hline H.50 & & & & & \\
\hline $\mathrm{H.52B}$ & & & 1 & & \\
\hline H.58 & & & 13 & & \\
\hline H.59 & & & 8 & & \\
\hline $\mathrm{H} .60$ & & & & & \\
\hline $\mathrm{H} .61$ & & & $\overline{24}$ & & \\
\hline H.63 & & & 2 & & \\
\hline H.64 & & & & 2 & \\
\hline H.67 & & & & 9 & \\
\hline $\mathrm{H} .73 \mathrm{~A}$ & & & & 2 & \\
\hline H.76 & & & & 1 & \\
\hline H.84 & & & & 1 & \\
\hline H.93B & & & & & 1 \\
\hline H.97 & & & & & 1 \\
\hline
\end{tabular}

Fig. 2. Presence of African red slipware in Monte de São Francisco according to Rodolfo Manaia

Sanz Serrano 2006, 125-150.

For some background on this location prior to the works, please refer to Carneiro 2014, vol. II, 10.56 (277279). Excavations took place under a request for permission to carry out urgent archaeological works and were later on included in the Research Project FRONTAGER IV as approved by Direcção Geral do Património Cultural (Inspectorate of Cultural Heritage) with the exclusive financial support of the Fronteira Municipality and scientific responsibility of the signatory. 
The data gathered in Monte de São Francisco are in line with the artefact serialisations of this region: around the mid- $5^{\text {th }}$ century, supplies from North Africa cease and become residual in archaeological records. After the enormous boost of the mid- $4^{\text {th }}$ century, a rapid decline follows with an abrupt fall around 520/550.

However, the dug-up reality in this archaeological site did not concern the villa's domestic space; an urgent excavation was necessary since a grave had been discovered during agricultural works. This excavation, which opened up a $32 \mathrm{~m}^{2}$ area, allowed for three graves to be identified. They all had a sepulchral enclosure formed by schist flagstones fixed into the rock formation and covered by other horizontal slabs (Fig. 3). These are individual places of burial with no artifactual assemblages, whatsoever facing East-West. Hence, around the late $5^{\text {th }}$ century or early $6^{\text {th }}$ century, in a specific part of the villa, burials are defining changes in the pattern of human presence in the site.

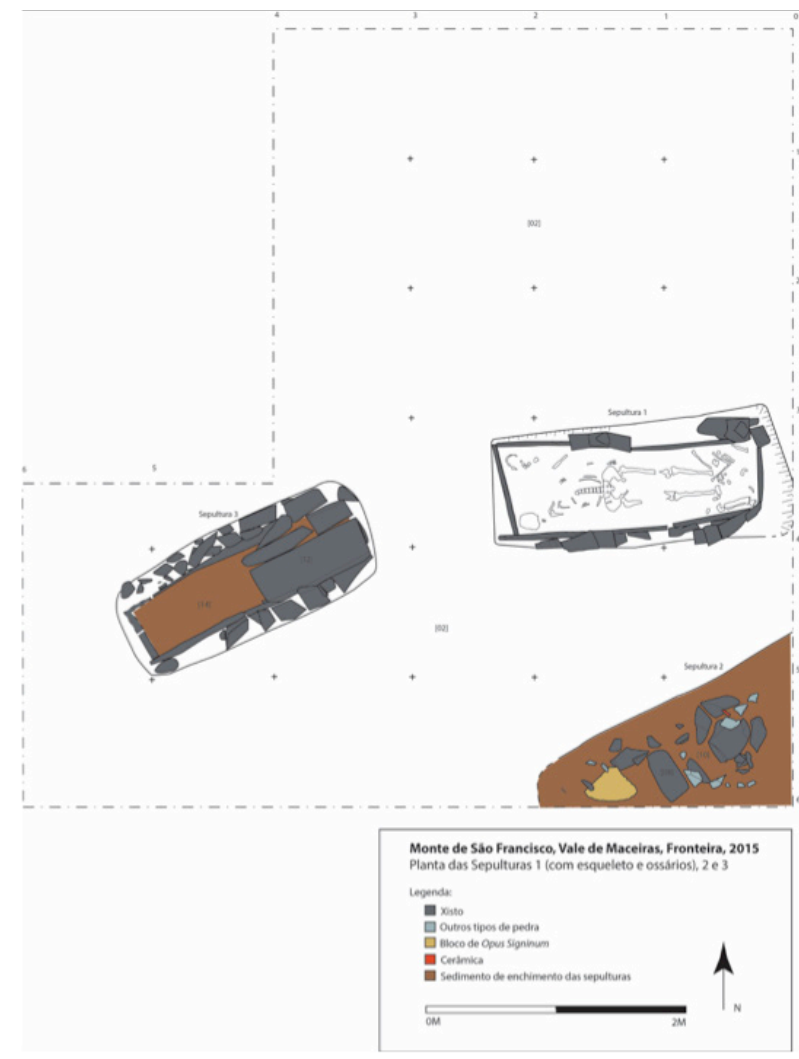

Fig. 3. Monte de São Francisco graves. Field drawing by Vanessa Dias

Excavations have been carried out since 2012, in the Roman villa of Horta da Torre, in the same territory and same municipality. ${ }^{8}$ This is a monumental residence and, right now, excavations are taking place in two different areas. In the first case, we have a big room representing the dominus, which is squared and ends with an

\footnotetext{
Carneiro 2014, vol. II, 266-268, 10.33. The archaeological and institutional background referred to in the
} previous note also applies. 
double apse, inside of which is the elevated stibadium in relation to the remainder of the enclosure. There was piping on the back wall, which allowed for water to enter as a cascade; this is why the entire floor in this room was covered in opus signinum, while the connection between the walls and the floor was covered in marble. Higher above, the walls were covered with polychrome mosaic tesselae, which came apart when the building's structure collapsed. The other area where excavation works are being carried out also documents the presence of water: it would come down from a fountain to the impluvium, which was located in the centre of a peristyle. This area was filled with columns, the floors were also covered in opus signinum, and the hall was covered by a dense overthrow of roof tiles mostly found in situ (Fig. 4).

The villa in Horta da Torre was abandoned in the mid- $5^{\text {th }}$ century, but it was later occupied again, before the building was reduced to ruins. In the heart of the great stibadium room, the opus signinum floor was drilled for a temporary residence to be built; the postholes of a longhouse are the evidence of this presence. This occupation took place before the walls fell plus their mosaic, which sealed this place with an over $50 \mathrm{~cm}$ dense fall. However, before this occurred, the new occupants plundered the marble tiles from the room by ripping them out from the walls. In the other area being dug up, in the peristyle -in the north-east corner, east of the fountain-, there is no overthrow of roof tiles: instead, this corner comprises a thick layer of ashes filled with rubble and residue from large fauna with shredded bones suggesting that it had been consumed. The fallen roof is obvious all around the remaining peristyle, although we still find fauna residue, which includes many bovine jaws, and fragments from large containers with manufacture procedures that remind us of the region's Iron Age ware. Whether they are in the large room, or in the peristyle, these later inhabitants literally lived among ruins, where they occupied the abandoned spaces in a way that is not connected whatsoever with the sumptuous way of life in the Roman era.

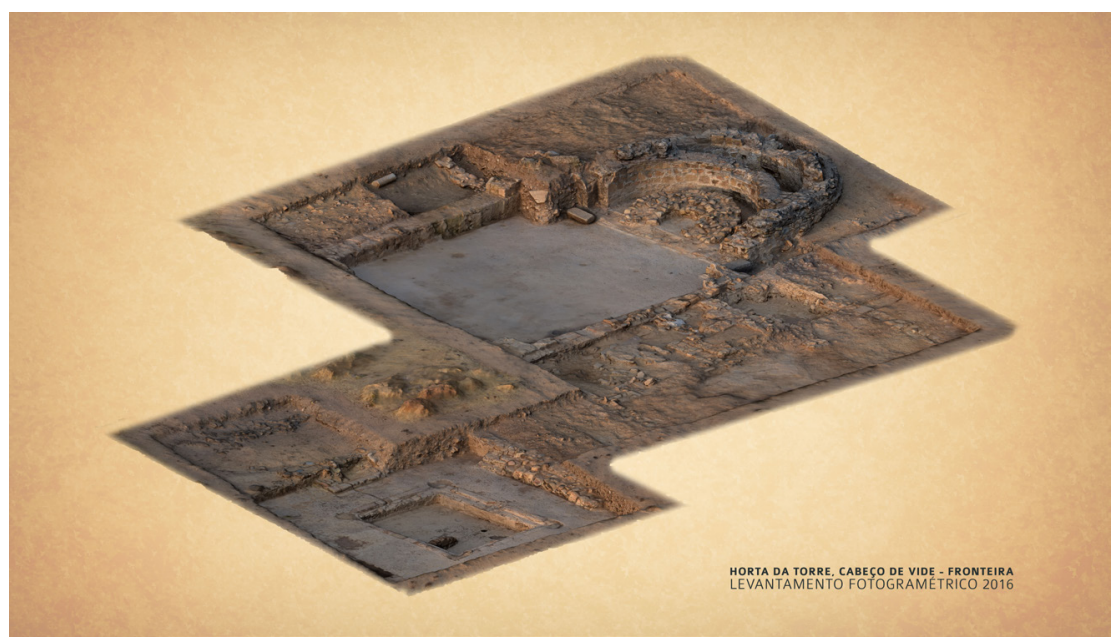

Fig. 4. Horta da Torre at the end of the 2016 campaign. Informatic treatment by Carlos Carpetudo 
The detected processes in the Fronteira sites are not a novelty. There are similar cases all around Alto Alentejo, just as I have outlined in other places, ${ }^{9}$ which are included in broader phenomena studied by several researchers: ${ }^{10}$

\begin{tabular}{|c|c|c|c|}
\hline $\begin{array}{c}\text { Forms of human } \\
\text { presence }\end{array}$ & Place Name & District & Observations \\
\hline \multirow[t]{6}{*}{$\begin{array}{l}\text { Reuses and re- } \\
\text { occupations }\end{array}$} & Argamassas & Campo Maior & Fireplace on mosaic \\
\hline & Quinta das Longas & Elvas & Holes on the floor \\
\hline & S. Vitória do Ameixial & Estremoz & $\begin{array}{l}\text { Fireplace; fauna } \\
\text { consumption }\end{array}$ \\
\hline & Monte de São Pedro & Fronteira & Space division; silos \\
\hline & Horta da Torre & Fronteira & Holes on the floor; fireplace \\
\hline & Torre de Palma & Monforte & $\begin{array}{l}\text { Restoration of mosaics; } \\
\text { fireplace }\end{array}$ \\
\hline \multirow[t]{8}{*}{ Necropolisation } & S. Salvador & C. Maior & $\begin{array}{l}\text { Necropolis outside the pars } \\
\text { urbana }\end{array}$ \\
\hline & S. Pedro dos Pastores & C. Maior & $\begin{array}{l}\text { Necropolis in the middle of } \\
\text { the structures }\end{array}$ \\
\hline & Ovelheira & Elvas & $\begin{array}{l}\text { Grave in an enclosure with } \\
\text { an apse in the middle of the } \\
\text { structures }\end{array}$ \\
\hline & Terrugem & Elvas & $\begin{array}{l}\text { Necropolis in the middle of } \\
\text { the structures }\end{array}$ \\
\hline & Silveirona/Coelha & Estremoz & $\begin{array}{l}\text { Necropolis in the middle of } \\
\text { the structures }\end{array}$ \\
\hline & Horta de S. Pedro & Sousel & $\begin{array}{l}\text { Necropolis in the middle of } \\
\text { the structures }(?)^{11}\end{array}$ \\
\hline & Pombais & Marvão & $\begin{array}{l}\text { Necropolisation of a } \\
\text { thermal building }\end{array}$ \\
\hline & Vale da Bexiga & $\begin{array}{l}\text { Castelo de } \\
\text { Vide }\end{array}$ & $\begin{array}{l}\text { Graves in the middle of the } \\
\text { structures }\end{array}$ \\
\hline
\end{tabular}

Fig. 5. Indicators of human presence in abandoned Roman villae (Carneiro 2016)

We have come to realise that there are two types of phenomena in this region:

i) abandoned sites, which shortly after their occupation for living purposes has ended and with their structures still in good condition, they are occupied once again in a timely and precarious manner.

\footnotetext{
9 For a broader perspective: Carneiro 2014, 241-274. For specific studies, please refer to Carneiro 2016 and the text introduced at Seminario Internacional Augusta Emerita y la Antiguedad Tardía (Mérida, 2015), which was handed in to be published into the concerned monography (Carneiro, in press).

10 I hereby refer the reader to the founding texts of this line of research: Ripoll - Arce 2001; Chavarría Arnau 2004a; 2007, 125-141.

11 Assumed from oral information: Carneiro 2014, vol. II, 17.20.
} 
ii) abandoned sites, which shortly after their occupation for living purposes has ended and with their structures still in good condition, they witness human presence yet again, although this time in the form of a funerary deposition for one or more burials.

As easily verified, both processes are exactly the same in terms of form, although their content is quite different: if, in their turn, the villae end their occupation period around the mid to late $5^{\text {th }}$ century, their reoccupation takes place within a maximum period of time of a century (considering a cycle up to four generations), since after that the houses entered into an irreversible process of turning into ruins. If we observe that reoccupation takes place while the structures are still in good condition, one can easily conclude that this process takes place a few tens of years at most before the roofs collapse for good. One can easily draw this conclusion as both phenomena will end up plundering, looting and/or using materials from the abandoned site, either by 'cleaning' the eventually abandoned materials in the house or by reusing them as a constant part of the furniture or funerary architecture. Those who walk in these areas are walking on the floors from the Imperial Era, before the ceilings and walls started to fall.

In the first case, the archaeological materials that were collected were relatively scarce, therefore it was easier to collect artefacts thrown into a bin or lost by accident than those on archaeological floor levels. For example, the case of the garbage in the villa at Quinta das Longas (Elvas) allowed for a substantial increase of the index of collected materials in this site, ${ }^{12}$ as this was not the case with excavation works in a residential context, where artefacts were somewhat scarce by comparison. In the previously mentioned case of the villa at Horta da Torre, the number of archaeological materials deposited above the floor levels is extremely low: for example, no coin or terra sigillata fragment has been found, so far, in the middle of fallen walls or fences, which tells us that this place was either intentionally abandoned or meticulously 'cleaned out' by those who reoccupied it. These indicators, which may be recorded for excavations with stratigraphic control, enable us to help in understanding how residences were abandoned.

In the second context, it is very well-known among other cases of funerary reuse the marble frieze belonging to a Roman building, richly decorated and reused as slabs for the necropolis grave at Silveirona (Estremoz), ${ }^{13}$ and there is also one that serves as a support for engraving the tombstone of Talass $a,{ }^{14}$ which used a finely cut slab decorated with acanthus leaves. One should remember that this necropolis, which probably accommodated a very significant number of people (Manuel Heleno, the archaeologist responsible for works on this site, has referred to over fifty graves -many of which included ossuaries-, hence increasing the universe of those buried to 70/80 individuals), has a very short epigraph time span of only one generation (513-544). However, this phenomenon was far more complex in another site of the same region. In Defesa de São Pedro, Campo Maior, ${ }^{15}$ a Roman site was partially dug up whose

\footnotetext{
Almeida - Carvalho 2005.

13 For more about the site, please refer to the comment section in Carneiro 2014, vol. II, 230-235, 09.07, with bibliographical references, in particular Cunha 2008.

Dias - Gaspar 2006, n 119.

Carneiro 2014, vol. II, 95-100, 05.15.
} 
occupation was never fully clarified, although judging from its closeness to the place where two milestones were collected, it may have served as a mansio. Nevertheless, the most important piece of information rests in the fact that these archaeological works -which were very limited as to minimise impact-identified a part of a peristyle, which ended in a compartment accessed through a gate with columns. This space was entirely renovated by 'shortening the room' so that a marble sarcophagus could be built therein, which contained an inhumation burial, hence creating a monumental mausoleum of exuberant dimensions (Fig. 6). The slabs covering this sarcophagus were reused from elements that decorated another spot in the same site. The peristyle -that is, outside the compartment- comprises other smaller burials, which amount to twelve overall. In short, in this, we do not only have the reuse of decorative elements in a residential context for funerary purposes, but the space itself was also redesigned in order to increase its monumentality so that a privileged ad sanctos burial may be incorporated, like the one in Silveirona, which polarises the following burials.

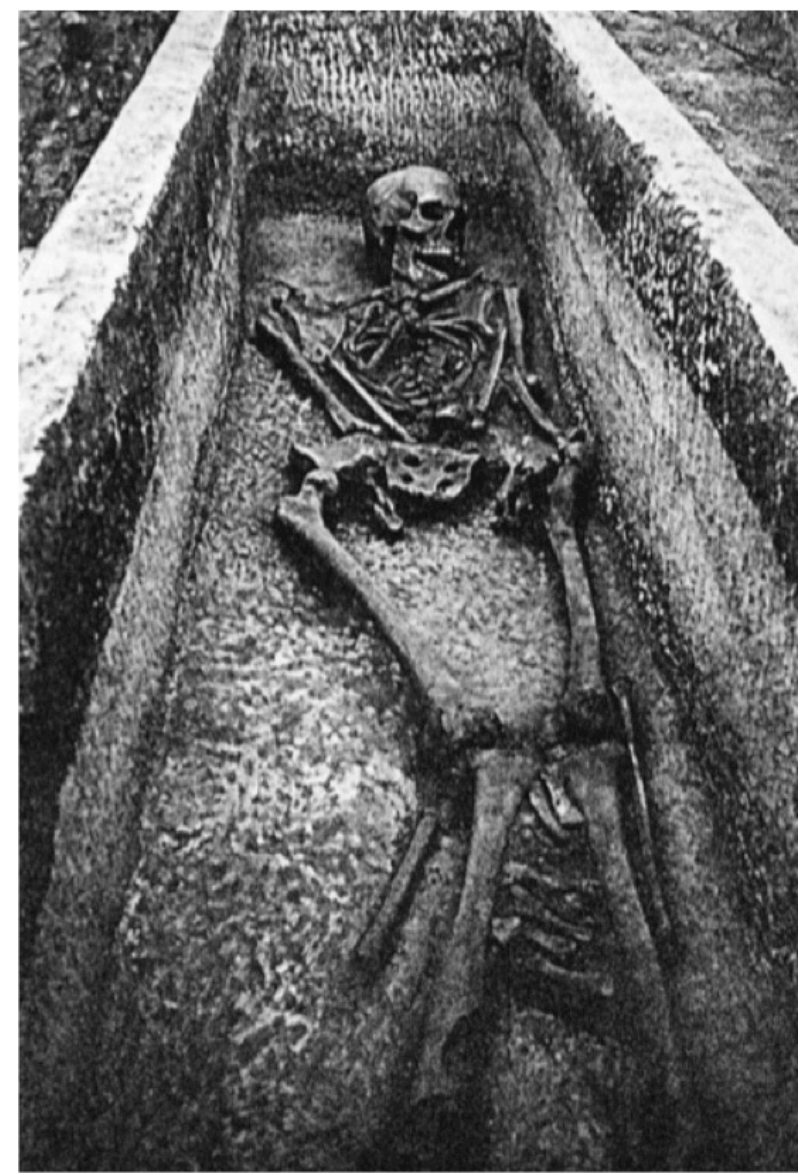

Fig. 6. Defesa de S. Pedro (Campo Maior) monumental grave. Unpublished report by Miguel Lago da Silva

In Lusitania, the most frequent phenomena that take place after the villae have been abandoned are the re-occupations and reuse for funerary purposes. Nevertheless, 
I would like to point out that more occurrences may be added to the elements that have been introduced: in the first case, re-occupations are difficult to perceive in archaeological terms, since there may be very little remains, which would not be found in previous excavation works, where all indicators of occupation above the floor level were carelessly removed in the search for the latter. Overall, only by carefully restudying those former excavations could one detect these phenomena. In the same way, funerary reoccupation may have been registered in other places besides those already mentioned, since these phenomena may occur in certain sectors of those sites, which partial excavations do not generally detect.

In any case, in spite of some sites breaking the rule, there seems to be a prevailing line of analysis: in the mid- $5^{\text {th }}$ century, the way in which the villa, in the traditional sense of the word, was inhabited, is completely lost. We must go back in time for a better understanding of how this phenomenon occurs.

\section{The end of the middle class: changes in the rural world}

The construction programme for the Alqueva dam contemplated systematic research of the territory and the possibility to carry out surveys in some of the well-known archaeological sites. The results were relevant, and for the Roman Imperial landscape, they enabled changes in some research paradigms.

One of the most interesting elements rests in the fact that we were able to confirm that the imperial landscape was sprinkled with housing developments or farms. This settlement pattern allowed single-family houses that raised livestock in the surrounding land, or in certain cases, explored specific niches (mining and fishing) with their own extensive agro-livestock autarchy. This base for survival allowed for its occupants to have a certain capacity of purchase, since most dwellings included in their repertoire import ware, glass, and coins that are characteristic of their occupation period. In some cases, there are indicators of comfort, and there is even a certain monumentality, which shows how the levels of prosperity became relevant. ${ }^{16}$ This is not the place to discuss whether this settlement pattern operated for the purpose of their own production or if these units explored lands in the fundus of a villa, although, from the surrounding context and absence of larger sites around, the first suggestion seems to be more likely. But the most important thing from this point of view is to mark the presence of this settlement network, which was extended towards the landscapes that were the most difficult to access, and with soils of lower agricultural capacity. Furthermore, looking at Lusitania, one can see how these average-sized units are ever-present in locations scattered around Alto Alentejo, ${ }^{17}$ as well as vast areas of the province.

This way, during the $1^{\text {st }}$ and $2^{\text {nd }}$ centuries, the fields were sprinkled with averagesized units, which -particularly in the peripheral territories that had not been occupied by the great villae- raised livestock in a few lands and/or maximised profit

16 The case of Xerez de Baixo 13, with two buildings and a total of 35 rooms (9+26), and Monte Branco 2, with its own small thermal building (Gomes - Brazuna - Macedo 2013). In the case of Monte da Charneca 4, a gold ring was collected in a site with quite modest structural components (Lopes 2013, 32). For more to the south, the case of Julioa 24 (Canhão 2004).

17 Carneiro 2014, vol. I, 131-135. 
in relevant market niches. Throughout this period of time, middle class peasantry who had achieved interesting levels of comfort and capacity of purchase- occupied the fields for several generations.

However, something changed in the late $3^{\text {rd }}$ century. In Lusitania, the occupation of peripheral territories and average-sized sites suffered a downturn, which resulted in their consistent abandonment regardless of the region where they were located. It is true that, as observed before, the peripheral areas with low potential were the first to be abandoned, while the areas with greater capacity remained in use. ${ }^{18}$ This ebbing has led the occupation indicators to levels prior to the time of Augustus, hence showing that the two first centuries of our Era were exceptional in terms of density of the sites accentuating the landscape ${ }^{19}$ However, the most relevant phenomenon does not rest solely on the abandonment of peripheral and less apt regions but rather on the observed retreat of the even more populated areas as we have witnessed an almost entire disappearance from these average-sized sites. An agricultural dwelling, or farm, or estate (depending on the researcher's designation) as a settlement pattern only lasted beyond the $3^{\text {rd }}$ century in very specific cases, for which we should consider economic and social reasons.

At the same time, the villae started a process of constructive reforms and expansion of the occupied area, which often took on a radical turn ${ }^{20}$ and was a force for the progressive monumentalisation of buildings. These phenomena are described in textual sources and are connected to the progressive concentration of rural properties leading to massa fundorum and the emergency of multiple owners who characterised the following centuries. ${ }^{21}$ An unstoppable process then began, which led to greater properties - which are not as many-leading to less sophisticated agricultural practices based on the extensive appropriation of territory. This dynamic led to the collapse of the imperial model in the following centuries $\left(4^{\text {th }} 5^{\text {th }}\right)$ when new alternatives started appearing in the settlement patterns, which tended towards the end of single-family structures and the reappearance of community concentrations that often reoccupied previously Roman sites. ${ }^{22}$

Beginning in the $3^{\text {rd }}$ century, we witness the retreat of average-sized rural sites. The social environment determining this phenomenon remains to be seen, as well as the way in which this peasantry organised itself through the following centuries: since the units where they lived were abandoned, which places became occupied throughout these times? And since the archaeological invisibility of this population was constant, either in life or in sepulchral spaces, how could one detect their presence in field survey or excavation?

18 In Jones 1973, 822, 20\% of abandoned area is estimated, although in regions like Alentejo, this might have been slightly higher.

19 For a broader view, Bintliff - Sbonias 1999, among others.

20 Just like the case of Quinta das Longas, where the designated villa I is entirely replaced by a new building set up over the previous one's structures without incorporating any of it into the new. Refer to Almeida - Carvalho 2005, fig. 11, 325.

21 The bibliography is immense on this subject, but consult specially Banaji 2007, 101-133; Wickham 2005, 383590; and the irreplaceable Jones 1973, 767-823. The texts tell us about elite that managed many properties: the case of Symmachus is very well-known, who used to manage his lands in Sicily and Mauritania from afar, since he had many constraints getting to the places. In other cases, the properties were spread around wider areas: Paulinus had lands in Aquitaine, as well as in Epirus, while Melania's possessions were spread out around areas that included the Italic Peninsula, North Africa, and Hispania.

22 This is the case of riverside settlements, hidden settlements, hill settlements, and dispersed settlements: Carneiro in press, item 2. This takes place around the whole province, not just in Alto Alentejo. 
Another open-ended question in this process is the way in which we can see, in archaeological terms, how these aristocratic elites were represented. Several authors enhanced the lack of their self-representation, ${ }^{23}$ and it is highly paradoxical that in a period of growing architectural monumentality and audacious decorations in the $4^{\text {th }}$-century monumental villae, there is at the same time scarce elite selfrepresentation formulae, in life and in death. ${ }^{24}$ This phenomenon is relevant, since it prevents us from building a prosopographical landscape and associating places with their inhabitants. Hence, we do not know anything about those that occupied the monumental villae, which due to their exuberance, seemed to be the residences of an influential elite that was perfectly aware of the representational formulae of their time. Contrast derives from the fact that these residences were extremely individualised in terms of taste and decorative programmes, which are in line with the popular models in the oikouméne, in terms of cultural content as well as social and identity representation. However, these families are not selfrepresented individually or in their lineage. In contrast to what texts indicate, ${ }^{25}$ we cannot find statues, iconography, or captions telling us about the members of the land elite, and even the mosaic emblemata bearing portraits or captions are dubiously interpreted.

The reinforcement of elite influence, which was visible in the exuberance of their residences -increasingly reproducing the formulae of architectural projects of the emperors-, seem to be in line with the disappearance of middle-class sites, hence indicating the power concentrated in the possessores and the wider gap in the economic capacity of all classes. This phenomenon grew even more in the $4^{\text {th }}$ century, when some villae started being abandoned or converted into productive spots, and were eventually incorporated into the fundi of other villae, hence reinforcing their productive capability.

This process is moving in line with another phenomenon, which is encouraged by the instability of these times: the reinforced authority of these land elite in the midst of the surrounding communities. Due to their financial power, political actions, and social and ideological representation, each elite takes on a role that is simultaneously stabilising and convening, ${ }^{26}$ hence reinforcing their ascendant onto the rural populations. It should be noted here that during Late Antiquity, power and influence did not depend on simple material issues, nor did it depend on wealth and the properties owned by each person: it depended, most of all, on a spiritual ascendant and the way in which communication codes and message broadcasting were handled. In this respect, a new leading character will change in a decisive manner the social relationships in Lusitania's fields: the Catholic Church.

\footnotetext{
Tamara Lewit was possibly the first author to take a deeper look at this phenomenon. Take a particular look at her 2003 study.

24 Please refer to Carneiro in press, item 4.

25 Since this matter goes side-by-side with the present study, and it may be dealt with in other texts, I would like to recall the texts by Ausonio, which mention a statue placed in one of his properties, hence giving continuity to a family tradition (villa at Lucaniacum: Aus. Ep. 14.36; 22.1; 44.2; 48.7), or Sidonio Apolinar's visit to the property of Pontius Leontius, who had painted the sigma peristyle walls with scenes that supposedly depicted his ancestors' successes (Sidon. Carm. 22.4-157).

26 Sanz Serrano 2007, 443.
} 


\section{Discourse of the souls: power and influence}

The previous table on the last forms of human presence within the scope of the villae did not report a phenomenon that is usually considered by researchers on the subject: the construction of Christian temples, whether inside the villa's structures or directly surrounding it. This is because the construction of a Christian topography deserves a more comprehensive look at it, since it constitutes a decisive factor for change between the $5^{\text {th }}$ and the $6^{\text {th }}$ centuries.

The Hispania Christianity phenomenon went through a silent stage, since according to the very few written references, almost no archaeological evidence matches it. ${ }^{27}$ Furthermore, the few existing data on this matter are fairly paradoxical, as it is the case of the crismon in the apse floor of one of the rooms in the villa at Quinta das Longas, which suggests the presence of a domus ecclesia that is practically contemporary to the great nymphaeum, with an absolutely classicist nature, in the opposite wing to the house's peristyle. ${ }^{28}$ These and other data remind us that the $4^{\text {th }}$ century probably included a rather pacific stage of coexistence between the pagan power and Christian religion in progressive installation.

As we already know, this situation will change in the following period. In the $5^{\text {th }}$ century, the church and Christian values progressively replaced the Roman power and the values of the fides and iustitia as standards in interpersonal relations. The texts on Lusitania give us two examples of this process' consolidation in the $6^{\text {th }}$ century, a time when social codes changed completely.

The first episode is written in Vitas Sanctorum Patrum Emeritensium ${ }^{29}$ and describes the story of the abbot Nancto, who arrived from Africa and lived for a year in Augusta Emerita before occupying a rural property (locum fisci) granted by King Leovigild. The workers were disappointed with the abbot's humble appearance, so they killed him. They were brought to royal justice, but the monarch left the issue to God's sentence stating that, since the abbot worked for the Church, he should not be involved. Although they were released, the workers were tormented by demons for several days until they suffered an atrocious death.

In the region of Évora, the text about the Passio in S. Manços narrates an episode that also shows the collapse in civil justice. In this case, it is a work from a later period ( $9^{\text {th }}$ century) describing events that also took place in the $6^{\text {th }}$ century, according to which the master of a rural worker forced him to renounce to his faith. After he refused, this martyr suffered terrible tortures that led to his death and those responsible were not punished.

This and other examples show the changes in the mental universe throughout a hundred years. Divine authority replaced the civil law, the administrative authority became useless, and the judicial authority is now exercised by those on the field, near the communities -the invisible power of those representing divine law. These men may be members of the Church hierarchy, or -as Christianity was being implemented in the fields- members of the rural elite, the possessores with a moral and social upgrade from the rustici in the surrounding communities, who assume the role of

It is important to remember the epistle of Cyprian of Carthage (Cypr. Ep. 64), dated from 254, which mentions a bishop and a Christian community in Augusta Emerita.

28 For some background on this problem, please refer to Carneiro 2014, vol. I, 241-274.

29 LVSPE 3.44. For some background on the questions placed in the text: Chavarría Arnau 2004b. 
a non-existing judicial power. Epigraphy and archaeological data provide us with a few indications in this field.

One of the most relevant phenomena in villae necropolisation rests in another process, that of the ad sanctos graves, or the creation of a funerary topography where a privileged burial would centralise later depositions. There are a few known cases in Lusitania: Defesa de São Pedro, which was previously described, is one of them, as it bears a sarcophagus that occupies a central position because it is not only in the centre of the room, but it is surrounded by the graves that followed. There is also the case of Terrugem (Elvas), where the graves surround an almost quadrangular construction made with great blocks of granite. The unequivocally Christian character of this necropolis was evaluated through a silver spoon that was collected bearing an inscription for use during liturgy. ${ }^{30}$ The previously mentioned case of Silveirona is even more eloquent. The layout repeats itself: an almost quadrangular building with solid construction masonry, which centralises burials placed around it in an almost chaotic fashion (that is, without the canonical sense of orientation). However, one of the graves was placed almost at the centre: the inscription on it identified the deceased as Sabinus, vir honestus ${ }^{31}$ someone that due to his actions in life occupied -in this burial space- a place of reference in the community's organisation. One should remember that, according to the preserved epigraphic testimonials, the chronological span of this necropolis is short -about a generation-, therefore one can assume that this community had strong bonds based on socialisation, which probably took place between all or most of the agents. This way, the emphasis placed on the grave of Sabinus is a reflection of his role in life, how he maintained his social bonds during a disturbed time, and his moral ascendant in the community. This expresses a new perception of how these rural societies were organised; the designation familia ecclesiae, which is often found in some council records, actually shows this perfectly. ${ }^{32}$

In their origin, these leading characters could have had two ascending lines in relation to the surrounding communities: partly de iure, so to speak, because they belonged to the Christian Church hierarchy; and partly de facto, because they were members of the most important families where they lived. We actually know that many of the main figures in Christian evangelism had these two conditions, ${ }^{33}$ which enabled them to have not just a symbolic action in their personal plan, but also practical actions in promoting the construction of basilicas and monasteries, hence creating a Christian topography in their domains.

Therefore, throughout these centuries, it is difficult to sort out whether we are looking at individual movements led by possessores or faithful aristocrats who are even a part of the Christian hierarchy, or if we are looking at a structured action carried out by the Church. Nevertheless, what actually seems clear is that the role of this second agent will become increasingly decisive: a shy presence in the fields throughout the $5^{\text {th }}$ century, the Church will have a more structuring role in the $6^{\text {th }}$ and $7^{\text {th }}$ centuries, and some evidence are pointing.

Let us look back (again) at the Mediterranean. We know that in the $7^{\text {th }}$ century there was a significant decrease of registered shipwreck, which is an indicator of a

Carneiro 2014, vol. II, 203-204, 08.47, with bibliographical references.

Dias - Gaspar 2006, $\mathrm{n}^{\circ} 114$, with references.

Such as canon 4 of the Council of Zaragoza.

Take a particular look at Sanz Serrano 2007, which has examples and many references. 
quick decline in marine traffic. ${ }^{34}$ However, until then, there were extremely revealing data regarding an active promoter in trade during the $6^{\text {th }}$ century.

Identifying the Yassi-Ada shipwreck has enabled us to recognise a wrecked ship some time before 626 . The vessel was carrying 822 amphorae, five of which had inscriptions on their neck identifying their content as a special kind of olive oil for liturgical purposes. ${ }^{35}$ An inscription on the ship itself (presbutero nauklero) may indicate that the captain was a member of the Church (and the vessel was probably property of the Church). ${ }^{36}$ The LR 1 and LR 2 amphorae seem to have been reused and were probably produced in a monastic complex in the island of Samos. Taking into consideration that this type of product requires special care in its manufacture and transportation, it is likely that the Church controlled its production. The Ramat Rahel Monastery, in Palestine, had an olive press in the $5^{\text {th }}$ and $6^{\text {th }}$ centuries, which produced amphorae that were specifically manufactured to serve as containers transporting highly important products. ${ }^{37}$

Another example of trade controlled by the Church that involves highly specialised products, which were probably for liturgical purposes, rests in the case of the late Roman unguentaria, which were identified in a Byzantine neighbourhood near Cerro de la Concepción (Cartagena), where the warehouses revealed "un carácter de almacenamiento que excede las necesidades domésticas" (a storage character that surpasses domestic needs). ${ }^{38}$ Small recipient fragments were found all over the city, but particularly in this area, from unguentarium or amphoriskos, which document trade control by members of civil administration (mostly eparches) as well as members of the Church in this process, since these pieces had alluding epigraphic seals. If the identification of these recipients used for the purpose of bottling olive oil, ointments, or perfume does not prove that they were used for religious purposes, it shows, however, that these perfumed and luxury liquids were also produced in monasteries, which controlled the product's distribution.

Although, due to their power and influence, individual clerics could also have the habit of consuming luxury goods, and that is where oriental products came in: in his texts, in Historia Francorum, bishop Gregory of Tours commented on how he appreciated exceptional wine that was transported from Gaza to Laodicea. Fortunately, the La Palud (Port-Cros) and Saint-Gervais (Fos) shipwrecks are a proof of this product circulation for luxury consumption. ${ }^{39}$ Nevertheless, the first shipwreck raises even more relevance due to the fact that some of the Keay 62 amphorae had Christian symbols graffiti in collo, which had been branded before the firing process, and could be an indication of the containers having been manufactured in some church oven ${ }^{40}$ in North Africa.

34 Referring again to Parker 1992, Chart 1.

35 For the background, see the studies in Jeffreys - Haldon - Cormack 2008. Take a look at the hypotheses suggested by Van Alfen 1996. For information on the shipwreck, please refer to http://nauticalarch.org/yassiadabyzantine-shipwreck-excavation-documents-and-drawings. I would like to particularly thank Sónia Bombico (CIDEHUS/UÉ) for the research tips.

36 Although the interpretation may be controversial: see Bass - Van Doorninck 1992, 314.

37 Quoting Arthur 1989, 86, since it was not possible to take a look at the monograph of Ramat Rahel excavations by Y. Aharoni 1964.

38 Vizcaíno Sánchez - Pérez Martín 2008, 153, with bibliography. The monograms show readable designations of Episcopal members of Rhodes, Iasus and Ephesus (Vizcaíno Sánchez - Pérez Martín 2008, 169).

39 Morrisson - Sodini 2002, 211, n. 238, with bibliography. For a more comprehensive view, please refer to Volpe 1998, 610-614.

40 Please refer to Fig. 8 in Long - Volpe 1996, 1253. For more on this subject, please refer to the comment and 
This bundle of data shows us that, although the West does not have the same vitality of Byzantine influence, it benefits from supply being taken back in the $6^{\text {th }}$ century, which replaced the North African inflow that was declining, in contrast -and which had prevailed over the $4^{\text {th }}$ century and part of the $5^{\text {th }}$ century, as mentioned in connection with the African red slip ware. Yet, as shown by the Marzamemi shipwreck and its ready-made church load, or any other shipwreck that contained ware recipients, the Church in fact promoted a part of the marine traffic. However, this movement was even broader as it shows how the Church produces and encourages a group of wide-ranging economic activities covering all cycles, from production/ attainment, transformation to the transport, distribution, and consumption. In this area, the Church replaced the Empire as the main facilitator of economic activities and circuits in the $6^{\text {th }}$ century, and their elite was the great promoter (and consumer) of these products.

Although the far West was a little further away from Mediterranean circuits, its indicators evidenced how this reality was actually experienced. The published map with the most relevant eastern indicators in Portuguese territory ${ }^{41}$ shows suggestive concentrations in Atlantic ports, as one could only expect, but it also shows interesting indicators of presence in inward territories, hence leading the author to suggest an

efectiva continuidade das ligações entre o mundo do Mediterrâneo oriental e o ocidente peninsular, [que nos] esclarece também sobre a dinâmica comercial das cidades costeiras, mas também sobre a efectiva permanência das redes de comunicação entre cidades e da sua capacidade de redistribuição para os núcleos rurais situados nos seus territórios. Em suma, dir-se-ia que nada de muito significativo distingue esta realidade da verificada no século IV.42

The Portuguese site where these connections between the East and the West may be better analysed is Mértola, former Myrtilis, where a constant contribution made by archaeological works has led to a permanent flow of new data for analysis. ${ }^{43}$ Even more than discussing a hypothetical Byzantine control, or the coexistence of different faiths -Christian, Orthodox, Arian, Jewish...-, it is beyond our call of duty to understand how the urbs and its rural territory (the ecclesiae in Montinho das Laranjeiras, by the Guadiana River, and Mosteiros, in the hinterland) were highly influenced by the eastern cultural universe, which was probably based on trade, in the existence of merchant communities, and a group of leading characters with religious influence in a highly hierarchical structure, as documented in the funerary epigraphy. One should also note that the contemporary policy of imperii recuperatio led to the engagement of trade currents for contact with North Africa -enabling, for example, a flow of imported African red slip ware in previous times-, which was replaced by the eastern trade routes in the $6^{\text {th }}$ century. This change is obviously noted in the

background section in Bernal Casasola 2007, 41-42, which includes the stimulating lines of research on the association between ecclesiastical institutions and production sites for preserved fish products (Bernal Casasola 2007, 39-41). Bernal Casasola takes a deeper look at this matter in a later article where he gives paradigmatic examples (Bernal Casasola 2010), some of which I have mentioned in the previous pages. See also Peña Cervantes 2008, with Hispanic examples.

41 Fabião 2009, particularly fig. 4-6.

42 Fabião 2009, 39.

43 Synthesis and balance of findings by Virgílio Lopes 2014. 
archaeological records, although there are no signs of the numbers achieved by North Africa in previous times. ${ }^{44}$ Although urban centres were left out of this analysis, it still remains remarkable to note that the recent amphora data registered for Ossonoba strengthen this view $^{45}$ by backing it up with other data that are becoming evident for the entire Atlantic seashore. ${ }^{46}$ Since this issue is much wider and worthy of an additional focus, it should be noted that the period of time between the $4^{\text {th }}$ century and the $7^{\text {th }}$ century is not a continuum, but it is rather a time of circumstances, cycles that were dictated by the outbreak of disruptions, new powers, the irruption of crisis and instability leading to changes in the former trade connections, often in short periods of time and different influences, among which the Byzantine floruit takes on a relevant role with different agents playing the leading roles at certain moments in time. What is happening in the Lusitania countryside?

The data are hard to read due to two factors: the lack of documents (which is the case, for example, in the north of Douro river, hence allowing for reading possibilities in the toponymical landscape) and the scarce sensibility of archaeologists in individualising late occupation moments, whether in artifactual detection, or in understanding the changing dynamics for sites and intra-sites. However, there seems to be a general moment of progressive land concentration, which in a first stage comprised the abandonment of middle-class sites in the $3^{\text {rd }}-5^{\text {th }}$ centuries, as previously mentioned, and in the mid-late $5^{\text {th }}$ century, the abandonment of the traditional occupation of the monumental villae in rural territories, after which the spaces were either reoccupied or turned into a necropolis.

However, data should be carefully analysed. In Milreu (Faro), the wine production site dating back to the first stage of villa construction was sacrificed in the $4^{\text {th }}$-century reforms, after which only two small spaces remain operational with a working volume that was very far from the previous period of time. In regard to the olive press, the five-press set was also abandoned during the 4thcentury reforms. That is, the site's productive capacity, which would probably have had supra-regional export, goes into decline very early on. ${ }^{47}$ Although the building activity continued, particularly with the construction of structures dedicated to the Christian cult, and some supply inflow remained into the site, ${ }^{48}$ its economic dynamics was clearly declining. Nevertheless, close to Milreu, by the coast, in Cerro da Vila (Vilamoura), there was a clear increase in activities that were associated with fish processing; although the reason is not quite clear, it may be related to trade flow into the East. However, the monumental environment is once again lost for good (in some cases, pipelines and storage areas have burst through the mosaic floors) and clearly shows the changes in the residence's living paradigm.

44 Please refer to, among other references, Volpe 1998, and the synthesis map of Giardina 1986, 178, fig. 11, and 217-219.

45 Almeida - Viegas - Beja - Teixeira, 2014, particularly the summary table in fig. 4 (157), which shows the replacement of North African inflow with eastern supplies around the mid-5th century.

46 Fabião 2009, 37, fig. 4-5. It is important to learn more about the role of private promoters in these connections with the east, such as the Syri mentioned in some texts and the Greek anthroponyms (García Moreno 1972, 130 and 138-140) that are present in the 6th-century epigraphy.

47 Teichner 2002, 112. Please take a look at the comprehensive review made by Peña Cervantes 2010, 950-954. The site's export dynamics is suggested by Teichner 2008.

48 Teichner 2008, 487-493. 
Taking a look at the province's inward territories, information is scarce and, at first sight, data seem to be contradictory. As previously stated, the $5^{\text {th }}$ century marked the collapse of the traditional way of life in villae: most sites, like Quinta das Longas, Horta da Torre, or São Cucufate (Vidigueira) were left abandoned, and the rare cases where human presence is shown from an archaeological point of view seem to be far different from the imperial world and the traditional paradigms. In Torre de Palma, the pars urbana seems to be on the fall but not exactly abandoned, as the mosaic floors show individual works carried out with opus signinum, and there is also evidence of re-occupation. Surprisingly, though, data points towards a moment with huge structural reforms to extend the wine lodge's productive capacity, which achieved its greatest working volume in the late $5^{\text {th }}$ century. ${ }^{49}$ What does this mean?

There are many possible explanations. The property could have grown while absorbing its surrounding domains, either by directly exploring the land, or by providing some kind of services for other properties. The stage where the Paleochristian basilica was mostly extended and the Baptistery was built may be an indication that Torre de Palma has become directly explored by the Church or some cleric with influence, hence strengthening its working capacity, which was now for the purpose of export. In this sense, the incised cross at the large weight of the olive press $^{50}$ shows the intent to integrate an element from an impure space into the order that is now effective, hence releasing it from the symbolic components of the previous world. Ultimately, the extension of the production area may also reflect an economic geo-strategic change, since the site may have based its previous production on other sources of income -particularly cereal- and started giving priority to viticulture and/or olive cultivation, which might explain the noticed lack of amphora elements collected during excavation works. ${ }^{51}$ Since this agent could have lived in the pars urbana, which, as mentioned before, showed signs of occupation, it should also be noted that the enigmatic north-eastern building, ${ }^{52}$ which has always been referred to but never conveniently described, could serve as a residence during this stage, although there was a good chance that it could have had more than one use, given the quantity of small compartments within this structure.

Without data enabling us to understand the agents and the causes leading to a stronger production in Torre de Palma, it is relevant to note that this phenomenon fits into broader dynamics around the entire province. The reinforced multiple-owners who purchase more and more large properties are constantly written about in literary texts: Santa Celerina and São Brissos left their large estate in the region of Évora in order to attend São Torpes burial, Melania tried to sell her properties in the peninsula, or one could recall the life of Abbot Paulus, who received an enormous land from a thankful aristocrat for saving his wife, as just a few examples. The land-based concentration is an unstoppable process throughout the $5^{\text {th }}$ century as productive sophistication decreases and is reduced to extensive cultures, while sophisticated working capacity is lost for market niches. It should be noted that one of the field

49 Lancha-André 2000, 81-82.

50 Lancha - André 2000, 117.

51 Although this datum cannot be overrated because the principle of systematic collection of artifactual components has only spread out in Portuguese Archaeology a few years ago; therefore, series of amphorae -such as common ware- are not included in the material that was collected in old excavation works.

52 Maloney 1995. 
leading characters throughout this stage is the Church, which also took on its business dynamics as clearly shown by the eastern world. It is not perfectly clear whether the same happened in Torre de Palma, but there are other data showing this situation.

In Baixo Alentejo, within less than six miles, two printed stamps were found in dolia walls. In Monte da Salsa (Serpa) -home to one of the most remarkable villae in the region of Beja-, there is the inscription Eclesiae Esce Marie Lacaltensi Agripi ${ }^{53}$ (Fig. 7.1), which is very similar to the ones in Herdade de São Cristovão, near the city of Moura: Eclesi(a)e S(an)ct(e) Mari(a)e Lacaltens(is) i(n) Agripi ${ }^{54}$ (Fig. 7.2). In spite of their problems from an interpretative point of view, especially due to the prayer to Mary -which is very precocious, since chronology pointed it towards the $6^{\text {th }}$ century- and the mention of a monastery and an urbs, which had not been heard of until now, there seems to be a case of correspondence between an agricultural property and a working/processing site. As a natural consequence, one could logically assume that the transported product and property owner would be the same in both locations. ${ }^{55}$
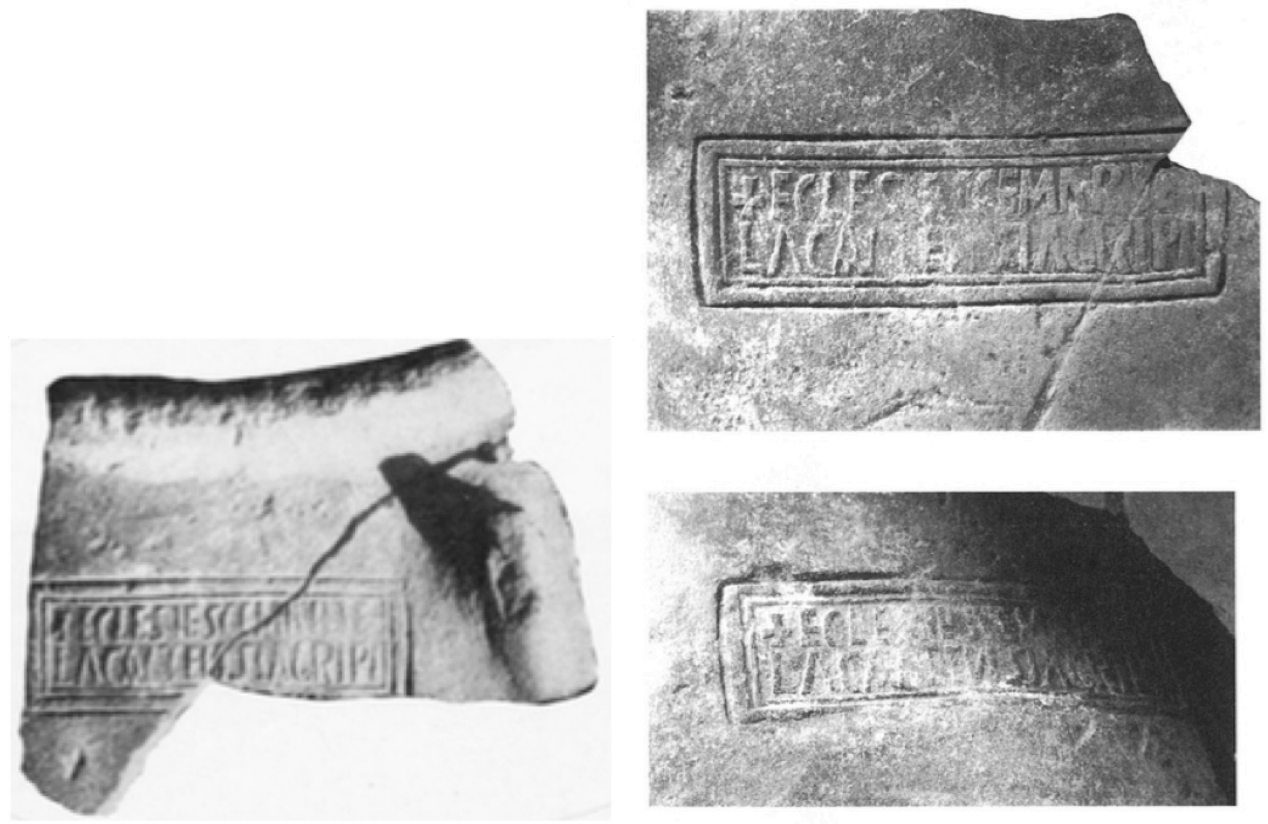

Fig. 7.1 (left) Monte da Salsa, dolium inscription (Almeida 1962, fig. 301). 2 (right) Moura, dolium inscription (Canto 1987, fig. 111)

The stamps from Monte da Salsa/Moura seem even more remarkable as they mention a monastery of Santa Maria, hence paralleling the inscriptions at the

53 Almeida 1962, 232, fig. 301 (Canto 1997, $\mathrm{n}^{\circ}$ 203; HEp 7, 1997, 1141). The notice is given by Abel Viana, who mentioned that "estes potes estavam enterrados a $1,70 \mathrm{~m}$ ou $1,80 \mathrm{~m}$ de profundidade" in a compartment shaped like a "rectângulo comprido com uma abside semicircular" (Viana 1955, 4-5), which is a suggestive indication but it does not allow for us to understand the use of this space.

54 Canto 1997, $\mathrm{n}^{\circ}$ 186, fig. 111-112 (HEp 7, 1997, 1135); and the recent publication in Macias - Valente - Gaspar 2014, 172, rising to four the dolia inscriptions in Moura urban centre.

55 See also Peña Cervantes 2008, 352-353. 
amphora necks that were found in Egypt (written with black ink) with the ones in the Danube (with red ink) by Tomasz Derda, ${ }^{56}$ where this prayer mentions the monastery or church land where these amphorae were packed. In the first case, the inscription on one amphora (I.1) could be interpreted as carrying 'sacred sweet oil' bearing the indication of its liturgical use as a parallel to another inscription in Sucidava, in the Danube Region. ${ }^{57}$ Since they are dated from the sixth century, it becomes plausible for the Church to control a significant part of the chain of production and distribution of highly specialised goods for trading and consumption purposes, simultaneously. In light of the obvious parallelisms, one may assume that the registered case in Monte da Salsa and Moura is similar, which makes the field/city readings even more suggestive, as well as the church's control over production, where the place names of the church or monastery responsible for production were documented, as in the cases presented by Tomasz Derda, along with the supervisor's anthroponyms. ${ }^{58}$ It should also be added that these places in Baixo Alentejo were significantly close to the Guadiana route.

The Church seems to progressively take on the main role in the territory's economic boost by creating mechanisms, which may enable it to ensure the social cohesion of communities - particularly in the rural environment-; it should, however, be noted that the process was a lot more complex, therefore it is worthy of deeper analyses.

As mentioned before, the settlement continuity indicators are scarce in the $5^{\text {th }}$ century villae. However, there is an interesting example in Monte da Cegonha (Vidigueira), where the whole structure undergoes an important reform in the late $4^{\text {th }}$ century followed by the site's necropolisation, where a few graves were built. However, the house remains inhabited with walls separating some dependencies. Although information is not explicit, the construction of an intra-villam basilica may date back to this time, which seems to coexist for some time with human presence in this residence, that is, the house was not abandoned (although its coexistence with the graveyard may raise doubts). This building's reform is only documented in the $6^{\text {th }}$ century, where the basilica took on more functions upon itself, since a marble reliquary box was placed by the altar containing a set of ware medals with decorated figures and maybe an ampula made of "liga de estanho e chumbo, com vestígios de ferro, cobre e prata" forming an ensemble with parallels in Syria, which leads the authors to consider that "poder tratar-se de um conjunto trazido por um peregrino dessa região ou então uma cópia fiel, feita in loco desses protótipos". ${ }^{59}$

The case of Monte da Cegonha provides us with many elements for reflection. Firstly, we are standing before a clear case of a private promoter building a place for Christian cult. Monte da Cegonha bears a Christian cultural environment with semi-public access - at least in a first stage--, although it is located inside the building (hence you can tell it apart from Torre de Palma, where the basilica was built outside the residence, although it was over an anterior funerary area). Therefore, in the Monte

\footnotetext{
Derda 1992, 137, and n. 15.

Derda 1992, 138, n. 21.

For other examples: Bernal Casasola 2010, 23.

Lopes - Alfenim 1994, 497. It should be noted that the interpretation made by the authors of a structure such as the Baptistery is troublesome, since it may be an aspersion font, which means that the background will be a different one for the presence of the Church at the site. The reliquary box was placed in the late 6th century or early 7 th century.
} 
da Cegonha case we have a dominus who renovated part of the residence in order to make it accessible for their familia ecclesiae, obviously taking advantage of an early period of time when the church's territory organisation had not been yet defined. Thus, we see how private actions - possibly by part of the secular aristocracy who took advantage of an early stage in the church's structure hierarchy to combine the jobs of guardian of the people and soul keeper- proceed to sort out the surrounding communities taking on the central role that polarises social relations. ${ }^{60}$ Nevertheless, during this stage one must obviously locate where the family managing the basilica resides, as in-between the building segmentation -with the construction of the temple- and the proliferation of graves among structures, there is not much space left for the domini to live in, unless the property owners lived somewhere nearby. In any case, the existence of an isolated marble sarcophagus in the south aisle with a privileged and different artefacts that those found in the other graves is an indication of a possible vir honestus, someone with a different status, therefore is placed at the centre of the site's funerary organisation. Whether it is the dominus or not, the later graves were placed around this burial. ${ }^{61}$

Monte da Cegonha is also a paradigmatic site for understanding a phenomenon of landscape symbolic topography, which Christianity will carry out as of the $5^{\text {th }}$ century and the leading character will not so much be private actions but rather the dynamics brought by the church hierarchy. Cases like Monte da Cegonha or, in Baixo Alentejo, the cult of the relics of São Fabião (Casével, Castro Verde) and São Romão (Panóias, Ourique) ${ }^{62}$ and Santo Lenho, in Vera Cruz de Marmelar (Portel), ${ }^{63}$ the cult institution to São Manços, in Évora, the martyrs in Tourega (Évora) or the consecrated epigraph to martyrs Iustus and Pastor in the church of São João dos Azinhais (Alcácer do Sal), ${ }^{64}$ among so many other examples, show this progressive phenomenon that was the creation of a landscape filled with symbolic references from the dominating universe, which reorganises our entire perception of space.

This process, which resorts to other mechanisms such as the creation of monasteries or reformulation of seats, will definitely create new coordinates in the perception of a new territory that is very different from the Hispania created by the Roman world. Throughout the centuries between the end of the Empire and the Muslim arrival, Lusitania received new leading characters in civil power and the religious sphere, who created a reality with new social, political, economic, and above all, symbolic relations. The loss of Hispania created a new universe, which is as complex and fascinating as all others, but allow us to point at a moment that has been generally ignored in the research, although it is tremendously rich in terms of content: this extended and complex $6^{\text {th }}$ century.

60 This view was common for the secular aristocracy as well as the clerics, who took on the role of protectors of the rural communities. The expression dominus et presbiter is clear in Canon XVIII of the Council of Mérida, in 666, which the clergy should undertake, hence managing production and workers.

61 Lopes - Alfenim 1994, 492.

62 Please refer to the study and references in Boiça - Torres 1993. The article focuses on a magnificent, silverplated piece, which was used as a São Fabião reliquary for tracing two cults and their regional incidence.

63 Although there is more recent bibliography, please refer to Almeida 1962, fig. 79, 81, 96, 115, 203, $222-226$.

64 Dias - Gaspar 2006, $\mathrm{n}^{\mathrm{o}}$ 161, with comments and bibliography. 


\section{References}

Almeida, F. (1962): “Arte visigótica em Portugal”, O Arqueólogo Português. Series II, 4, 5- 278.

Almeida, M. J. - Carvalho, A. (2005): “Villa romana da Quinta das Longas (Elvas, Portugal): a lixeira baixo-imperial", Revista portuguesa de Arqueologia 8/1, 299-368.

Almeida, R. R. - Viegas, C. - Beja, N. - Teixeira, N. (2014): “Ânforas do Mediterrâneo oriental em Faro (Ossonoba): novos dados para equacionar o comércio durante a Antiguidade Tardia", [in] R. Morais - A. Fernández - M. J. Sousa (eds.), As produções cerâmicas de imitação na Hispania (=Monografias Ex Officina Hispana II), Porto, Tomo II, 151-160.

Arce, J. (2002): Mérida Tardorromana (300-580 d. C.), (=Cuadernos Emeritenses 22), Mérida.

Arthur, P. (1989): "Aspects of Byzantine Economy: an Evaluation of Amphora Evidence from Italy”, [in] V. Déroche - J.-M. Spieser (éds.), Recherches sur la céramique Byzantine. Athens 1987 (=Bulletin de correspondance Hellénique. Suppl. 18), Athens, 79-93.

Balletti, C. - Beltrame, C. - Costa, E. - Guerra, F. - Vernier, P. (2015): "Underwater photogrammetry and 3D reconstructions of marble cargos shipwreck", [in] The International Archives of the Photogrammetry, Remote Sensing and Spatial Information Sciences (16-17 April 2015), (=Volume XL-5/W5 Underwater 3D Recording and Modelling), Piano di Sorrento, 7-13 (http://dx.doi.org/10.5194/isprsarchives-XL5-W5-7-2015).

Banaji, J. (2001): Agrarian Change in Late Antiquity: Gold, Labour and Aristocratic Dominance, Oxford.

Bass, G. F. - Van Doorninck, F. H. (1992): Yassi Ada, volume I - A Seventh-Century Byzanthine Shipwreck, Texas.

Bernal Casasola, D.

(2007): "El final de la industria pesquero-conservera en Hispania (ss. V-VII d.C.). Entre obispos, Bizancio y la evidencia arqueológica", [in] J. Napoli (ed.), Ressources et activités maritimes des peuples de l'Antiquité (=Les Cahiers du Littoral 2/6), Boulogne-sur-Mer, 31-58.

(2010): "Iglesia, producción y comercio en el Mediterráneo tardoantiguo. De las ánforas a los talleres eclesiásticos", [in] S. Menchelli - S. Santoro - M. Pasquinucci - G. Guiducci (eds.), LRCW3 Late Roman Coarse Wares, Cooking Wares and Amphorae in the Mediterranean: Archaeology and Archaeometry. Comparison between Western and Eastern Mediterranean (=BAR International Series 2185), Oxford, vol. I, 19-31.

Bintliff, J. - Sbonias, K. (eds.), (1999): Reconstructing Past Population Trends in Mediterranean Europe (=The Archaeology of Mediterranean Landscapes 1), Oxford (https://doi.org/10.2307/j.ctvh1dqhd).

Boiça, J. - Torres, C. (1993): “A cabeça - relicário de Casével”, Arqueologia Medieval 2, 229-242.

Canhão, V. (2004): "O sítio romano da Julioa 24 (nova aldeia da Luz)", Museu da Luz Arqueologia nas terras da Luz, 67-75.

Canto, A. Ma (1997): Epigrafía romana de la Beturia Céltica (=UAM Ediciones. Colección de Estudios 54), Madrid.

Carneiro, A.

(2014): Lugares, tempos e pessoas. Povoamento rural romano no Alto Alentejo (=Universidade de Coimbra. Humanitas, Suppl. 30), Coimbra, 2 vols. + CD-ROM 
(2016): "Mudança e continuidade no povoamento rural no Alto Alentejo durante a Antiguidade Tardia", [in] J. d'Encarnação - C. Lopes - P. C. Carvalho (eds.), A Lusitânia entre romanos e bárbaros, Coimbra, 281-307.

(in press): "Entre dois rios. Povoamento e território no Alto Alentejo durante a Antiguidade Tardia”, Seminario Internacional Augusta Emerita y la Antiguedad Tardía (Mérida, 2015).

Chavarría Arnau, A.

(2004a): "Considerazioni sulla fine delle ville in Occidente", Archeologia Medievale 31, 7-19.

(2004b): "Monasterios, campesinos e villae en la Hispania visigoda: la trágica historia del Abad Nancto", [in] C. Balmelle - P. Chevallier - G. Ripoll (eds.), Studiola in honorem Noël Duval (=Bibliothèque de l'Antiquité Tardive 5), Turnhout, 113-125.

(2007): El final de las villae en Hispania (siglos IV-VIII), (=Bibliothéque de l'Antiquité Tardive 7), Turnhout.

Cunha, M. (2008): As necrópoles de Silveirona (Santo Estêvão, Estremoz). Do mundo funerário romano à Antiguidade Tardia (=O Arqueólogo português. Supl. 4), Lisboa.

Derda, T. (1992): "Inscriptions with the Formula 'theou haris kerdos' on Late Roman Amphorae", Zeitschrift für Papyrologie und Epigraphik 94,135-152.

Dias, M. M. A. - Gaspar, C. (2006): Catálogo das inscrições paleocristãs do território português, Lisboa.

Fabião, C. (2009): “O Ocidente da Península Ibérica no século VI: sobre o pentanummium de Justiniano I encontrado na unidade de produção de preparados de peixe da casa do governador da Torre de Belém, Lisboa", NIA-ERA Apontamentos de Arqueologia e Património 4, 25-50.

García Moreno, L. (1972): “Colonias de comerciantes orientales en la Península Ibérica. S. V-VII”, Habis 3, 127-154 (https://doi.org/10.12795/Habis.1972.i03.06).

Gomes, S. - Brazuna, S. - Macedo, M. (2013): A ocupação romana na bacia de Alqueva: da ponte de Ajuda à ponte velha de Mourão (=Memórias d' Odiana 2. ${ }^{\mathrm{a}}$ série 8 ), Évora.

Jeffreys, E. - Haldon, J. - Cormack, R. (eds.), (2008): The Oxford Handbook of Byzantine Studies, Oxford (https://doi.org/10.1093/oxfordhb/9780199252466.001.0001).

Jones, A. H. M. (1964): The Later Roman Empire, 284-602. A Social Economic and Administrative Survey, Oxford, 2 vols.

Kapitän, G. (1980): "Elementi architettonici per una basilica dal relitto navale del VI secolo di Marzamemi (Siracusa)", [in] Atti del XXVII corso di cultura ravennate e bizantina (Ravenna 1980), Bologna-Ravenna, 71-136.

Laiou, A. E. (ed.), (2002): The Economic History of Byzantium: From the Seventh through the Fifteenth Century, Washington.

Lancha, J. - André, P. (2000): Corpus dos mosaicos romanos de Portugal. II - Conventvs Pacensis. $1-A$ villa de Torre de Palma, Lisboa, 2 vols.

Lewit, T. (2003): "Vanishing villas': what happened to élite rural habitation in the West in the 5th-6th c.?", Journal of Roman Archaeology 16, 260-274 (https://doi.org/10.1017/ S104775940001309X).

Long, L. - Volpe, G. (1996): “Origini e declino del commercio nel Mediterráneo occidentale tra età arcaica e Tarda Antichità. I relitti della Palud (Isola de Port Cros, Francia)", [in] M. Khanoussi - P. Ruggeri - C. Vismara (eds.), L'Africa Romana. Atti del XI Convegno di studi. Cartagine 15-18 dicembre 1994, Sassari, 1235-1284.

Lopes, C. (2013): Em tempos de Roma pela margem esquerda do Alqueva (=Memórias d' Odiana, 2. ${ }^{a}$ série 9), Évora. 
Lopes, M. C. - Alfenim, R. (1994): “A villa romana do Monte da Cegonha”, [in] J. M. Campos - J. A. Pérez - F. Gómez (eds.), Arqueología en el entorno del Bajo Guadiana, Huelva, 485-502.

Lopes, V. (2014): Mértola e o seu território na Antiguidade Tardia (séculos IV-VIII), Doctoral Thesis, University of Huelva.

Macias, S. - Valente, J. G. - Gaspar, V. (2014): “Lacalt e Laqant: da toponímia antiga à islamização", [in] S. Gómez Martínez - S. Macias - V. Lopes (coords.), O Sudoeste Peninsular entre Roma e o Islão, Mértola, 138-165.

Maloney, S. J. (1995): “The early Christian basilican complex of Torre de Palma (Monforte, Alto Alentejo, Portugal)", [in] IV Reunio d'Arqueologia Cristiana Hispànica (Lisboa 2830 de setembre, 1-2 octubre de 1992), Barcelona, 445-458.

McCormick, M. (2012): "Movements and Markets in the First Millennium: Information, Containers and Shipwrecks", [in] C. Morrisson (ed.), Trade and Markets in Byzantium, Washington, 51-98.

Morrisson, C. - Sodini, J.-P. (2002): “The sixth-century economy”, [in] Laiou (ed.), 2002, 169-220.

Parker, A. J. (1992): Ancient Shipwrecks of the Mediterranean and the Roman Provinces (=BAR International Series 580), Oxford.

Peña Cervantes, Y.

(2008): "La producción de vino en contextos eclesiásticos tardoantiguos hispanos", [in]

J. Blánquez Pérez - S. Celestino Pérez (eds.), El vino en época tardoantigua y medieval (=Universidad Autónoma de Madrid. Varia 8), Madrid, 343-355.

(2010): Torcularia. La producción de vino y aceite en Hispania (=ICAC. Col·lecció Documenta 14), Tarragona.

Ripoll, G. - Arce, J. (2001): “Transformación y final de las villae en occidente (siglos IVVIII): problemas y perspectivas", Arqueología y territorio medieval 8, 21-54 (http:// dx.doi.org/10.17561/aytm.v8i0.1672).

Sanz Serrano, R.

(2006): "Las migraciones del siglo V en la Península Ibérica: nuevas perspectivas", [in] G. Bravo - R. González Salinero (eds.), Minorías y sectas en el mundo romano. Actas del III Coloquio de la Asociación Interdisplinar de Estudios Romanos (=Signifer. Monografías y Estudios de Antigüedad Griega y Romana 20), Madrid, 125-150.

(2007): “Aristocracias paganas en Hispania Tardía (s. V-VII)”, [in] D. Plácido - F. J. Moreno Arrastio - L. A. Ruiz Cabrero (eds.), Necedad, sabiduría y verdad: el legado de Juan Cascajero (=Gerión, Extra 1), Madrid, 443-480.

Sodini, J.-P. (2002): "Marble and stoneworking in Byzantium, seventh to fifteenth centuries", [in] Laiou (ed.), 2002, 129-146.

Teichner, F.

(2002): "Resultados preliminares das últimas excavações na parte rústica noroeste da Villa Romana de Milreu”, [in] R. V. Gomes (ed.), Actas do 1 Encontro de Arqueologia do Algarve (=Xelb 4), Silves, 104-114.

(2008): Entre tierra y mar (Zischen Land und Meer). Arquitectura y economía en el sur de la Lusitania romana (Architektur und Wirtschaftsweise im Süden der römischen Provinz Lusitanien (=Studia Lusitana 3), Mérida.

Van Alfen, P. G. (1996): "New light on the 7th c. Yassi Ada shipwreck. Capacities and standard sizes of LRA1 amphorae", Journal of Roman Archaeology 9, 189-213 (https:// doi.org/10.1017/S1047759400016561). 
Viana, A. (1955): "Notas históricas, arqueológicas e etnográficas do Baixo Alentejo”, Beja archives XII, 3-35 (extract with its own number sequence).

Vizcaíno Sánchez, J. - Pérez Martín, I. (2008): "Ungüentarios bizantinos con sello epigráfico en Carthago Spartaria", Archivo Español de Arqueología 81, 151-176 (https://doi. org/10.3989/aespa.2008.v81.44).

Volpe, G. (1998): “Archeologia subacquea e commerci in età tardoantica”, [in] Archeologia subacquea. Come opera l'archeologo sott'acqua. Storie dalle acque, Firenze, 561-626.

Wickham, C. (2005): Framing the Early Middle Ages. Europe and the Mediterranean 400800, Oxford (https://doi.org/10.1093/acprof:oso/9780199264490.001.0001).

Wolfram, M. (2013): “O poder durante a Antiguidade Tardia no Império romano ocidental e na Lusitania em particular”, [in] F. Cerqueira - A. T. Gonçalves - E. Medeiros - D. Leão (orgs.), Saberes e poderes no mundo antigo. Volume II. Estudos ibero-latino-americanos - Dos poderes, Coimbra, 283-293. 